\title{
RIGHTS OF MIGRANTS: NOTES ON THE JURISPRUDENCE OF THE INTER- AMERICAN COURT OF HUMAN RIGHTS
}

\author{
María Teresa Palacios Sanabria \\ maria.palacios@urosario.edu.co \\ Doctor in Law and holder of a Master degree in Constitutional Law from Universidad de Sevilla, \\ Spain. Associate Professor at the Universidad del Rosario (Colombia) and lawyer of the \\ Universidad del Rosario. Director of the Human Rights Research Group of the Faculty of \\ Jurisprudence of the Universidad del Rosario.
}

\begin{abstract}
The rights of migrants represent a challenge for States, because their guarantee evidences the permanent tension between the sovereignty of the States and the protection of human rights in the international context. This article will analyse if it is really possible to affirm the existence of a true evolutionary development of the jurisprudence of the Inter-American Court of Human Rights in a contentious and consultative way and which, therefore, may contribute to the improvement of the rights of migrants in the IACHR. To this end, the text will address the following parts: I) Regulatory framework oriented to the sovereignty of States; II) The progressive contentious jurisprudence of the Inter-American Court III) The advisory opinions: integrating elements of rights and; IV) Conclusions.
\end{abstract}

\section{Keywords}

Human rights, Inter-American Court of Human Rights, progressive development, interAmerican jurisprudence, international migration

\section{How to cite this article}

Sanabria, María Teresa Palacios (2019). "Rights of migrants: notes on the jurisprudence of the Inter-American Court of Human Rights". JANUS.NET e-journal of International Relations, Vol. 10, N.0 2, November 2019-April 2020. Consulted [online] on the date of the last visit, https://doi.org/10.26619/1647-7251.10.2.9 


\title{
RIGHTS OF MIGRANTS: NOTES ON THE JURISPRUDENCE OF THE INTER- AMERICAN COURT OF HUMAN RIGHTS ${ }^{1}$
}

\author{
María Teresa Palacios Sanabria
}

\section{Introduction}

The human rights recognized in international treaties are predicated by all people and International Human Rights Law (IACHR), under the claim of universality ${ }^{2}$ (UN, 1993: 19), has established the reasons why they cannot have discriminatory treatment. ${ }^{3}$ The Inter-American System for the Protection of Human Rights (SIDH) has not been the exception and, through the evolution that it has had regarding the emergence of its bodies, regulations and jurisprudence, has been concerned with establishing parameters for the protection of human rights in the American region, applicable to all persons subject to the jurisdiction of the member states. Thus, it is evidenced by the treaty establishing the Organization of American States (OAS), by pointing out in Article 3.i that: "The American States proclaim the fundamental rights of the human person without distinction as to race, nationality, creed or sex" (OAS, 1948).

With the creation of the Inter-American Commission on Human Rights (IACHR) in 1959 and subsequently the Inter-American Court (1969), as well as with the adoption of general regional treaties and thematic sectorial treaties, a process of evolutionary development of regional jurisprudence was promoted, which determines the scope of the obligations of the States party to them and accept the jurisdiction of the court for the monitoring of the fulfilment of such commitments.

Thus, it is up to the Inter-American Court, as supreme autonomous and judicial authority of the IACHR, to apply and interpret the provisions contained in the ACHR. Both contentious decisions and the advisory opinions of the Court have dealt with a great diversity of issues and rights and have been described by some doctrine makers as progressive, courageous and committed to the application of the "pro persona" principle, which has implied the extension of the catalogue of rights contained not only in the ACHR,

1 The translation of this article was funded by national funds through FCT - Fundação para a Ciência e a Tecnologia - as part of OBSERVARE project with the reference UID/CPO/04155/2019, with the aim of publishing Janus.net. Text translated by Carolina Peralta.

2 See the Vienna Declaration and Action Programme (article 5, 1993).

3 Universal Declaration of Human Rights, (art. 2, 1948) and the 1966 agreements. See definition of discrimination in the International Convention on the Elimination of All Forms of Racial Discrimination (article $1.1,1965)$. 
but in the other treaties that are part of this regional context (Quispe, 2016: 229) (Núñez, 2017: 80) (Ovalle, 2012: 601).

Although a significant number of rights are recognized to every person, in the case of foreigners, countries can legitimately establish distinctions that are not considered prohibited, which question the principle of equality (Lucas, 2015: 90). Consequently, it is common for their exercise to be restricted to a very limited framework, which is present in migration policies. In parallel, the reality of migration is increasing and according to the OAS, between 2012 and 20167.2 million people left their country in the Americas (OAS, 2017: 4). In this context, it is of interest to analyse how the contentious and advisory jurisprudence of the Inter-American Court has behaved in this area, and identify which are its main contributions in order to demonstrate the beginning of the construction of an emerging normative corpus on the rights of foreigners and migrants, which results in the creation of interpretative parameters for the OAS member states, but which at a comparative level can inspire developments in other regional contexts.

The document is the result of research on a project called "The right to a dignified life in the context of immigration"4, which uses a dogmatic methodology of documentary analysis of primary normative, jurisprudential and doctrinal sources of the IACHR, but which in this case will focus on the activity of the Inter-American Court, although reference to the reports of the IACHR, as well as to other instruments that are part of the IACHR corpus, may be made

\section{A normative framework oriented to the sovereignty of States}

\subsection{American Declaration of $\mathbf{1 9 4 8}$}

In order to refer to the decisions of the Inter-American Court of Human Rights, it is necessary to review some regional norms such as the American Declaration of Rights and Duties of Man of 1948 (DADH) $)^{5}$ since it provides that the (...) the American States have recognized that the essential rights of man do not arise from the fact of being a national of a certain State but are based on the attributes of the human person" (OAS, 1948 A: 1).

This leads to reflection on the true notion of equality between people, in which the value of individuals prevails without taking into account any legal-political considerations with the territories for the allocation of rights. However, this ideal is diluted as in the operative part of the American Declaration of the Rights and Duties of Man DADH, art. II, the nationals of the States are only recognized the right to select their residence and to move freely through the territory, and allusion to the right of entry is omitted. For its part, the Universal Declaration of Human Rights ${ }^{6}$ (UDHR) does expressly recognize in Article 13 the right of entry, without this being replicated in subsequent regulatory developments. ${ }^{7}$ This may be due to the entrenched concept of sovereignty of the States that translates

The aforementioned project is part of the doctoral work conducted at the University of Seville, which ended in 2012, but continues to generate products given the author's interest in the theme.

5 Signed in Bogotá in 1948 and amended by the Protocol of Buenos Aires in 1967, by the Protocol of Cartagena de Indias in 1985, by the Protocol of Washington in 1992, and by the Protocol of Managua in 1993.

6 Adopted by the General Assembly of the United Nations on 10 December 1948, by resolution 217 A (III).

7 The right of entry is not recognized in the ICCPR or in the regional treaties. 
into the design of immigration policy through visas, entry controls and permanence of foreigners. ${ }^{8}$

\subsection{Some applicable treaties}

The normative omission of the right of entry is evidenced in the American Convention on Human Rights (ACHR) ${ }^{9}$ in Article 22, which states that: "Everyone who is legally in the territory of a State has the right to move through it and to reside in it subject to legal provisions" (OAS, 1969: 8). This is a reproduction of the provisions in the universal context, since the ICCPR of $1966^{10}$ in article 12 conditions the right of entry, freedom of movement and residence, to persons who are legally within the territory of the State. UN, 1966). ${ }^{11}$ In accordance with the foregoing, it is clear that for the current IACHR, the right of entry is non-existent and that from there, the States retain a high margin of discretion that materializes in the restrictive exercise of the rights of foreigners.

In addition, the International Convention on the Elimination of All Forms of Racial Discrimination (UN, 1965), in defining discrimination excludes the distinctions that happen through the application of the concept of citizenship and non-citizenship (art.1.2 CERD), empowering countries to grant differentiated treatment not constituting discrimination (Palacios, 2012).

\section{The progressive contentious jurisprudence of the Inter-American Court in favour of the rights of migrants}

In the previous section some basic norms were enunciated, from which the States limit the exercise of the rights of foreigners, evoking their national security, public order or general interest. For this reason, it is appropriate to analyse the characteristics that the jurisprudence of the Inter-American Court has had in this matter, since the court turns to various methods of interpretation provided for in the Vienna Convention on the Rights of Treaties (OImos, 2017: 3). This will allow us to identify elements that demonstrate the existence of a true evolutionary development that establishes some limits to the sovereignty of States regarding the treatment of foreigners. In this reflection, progressive development of human rights is understood as the normative and jurisprudential evolution that results in the greater protection of the rights of foreigners as a path to restricted equalization (Gomez, 2003). On the other hand, it is valuable to examine to what extent the Inter-American Court makes use of its two functions to complement the framework of the rights of foreigners, that is, if the considerations it reaches in the exercise of the contentious function are replicated in the jurisprudence of the consultative order.

8 Article 13 of the UDHR: "Everyone has the right to move freely and to choose his residence in the territory of a State. Everyone has the right to leave any country, including his own, and to return to his country".

9 Adopted in San José, Costa Rica, on 22 November 1969, effective on 18 July 1978.

10 Adopted and open for signature, ratification and accession by the General Assembly in its resolution 2200 A (XXI) of 16 December 1966, effective on 22 March 1976.

11 Article 12.1. Any person who is legally in the territory of a State shall have the right to move freely through it and to freely choose his residence therein. 


\subsection{A timely and guarantee ensuring jurisprudence}

The contentious function of the Inter-American Court is set forth in Articles 61, 62 and 63 of the ACHR and is regulated in several norms of the Regulations of the same corporation (OAS, 2009). The main purpose of this competence is to carry out a process of normative application to specific facts to determine whether or not there were violations in the light of the ACHR and derive from there international responsibility against the alleged infringing State. Therefore, the Inter-American Court must issue a judgment in which it will have to provide for measures of reparation, satisfaction or guarantees of non-repetition. (Roa, 2015:64). This is how it is up to it to verify the veracity of the denounced facts and decide if they can be considered a violation of the ACHR. (Ventura and Zovato, 1989:165). Although the cases ruled by the Inter-American Court regarding the rights of foreigners are not very numerous ${ }^{12}$, some issues can be identified, including the right to nationality, expulsion of foreigners and respect for the principle of non-refoulement, equality and non-discrimination, judicial guarantees and due process.

\subsubsection{The right to nationality is related to other guarantees}

The Ivcher Bronstein vs. Peru ${ }^{13}$ case $\left(I_{A C H R}, 2001\right)$ sets a parameter for the protection of the right to nationality by adoption of a naturalized Israeli citizen in Peru who had previously renounced his nationality of origin and who, due by a decision of an authority without competition, was at risk of statelessness. The Inter-American Court describes the right to nationality as a natural and inherent state of the human being (IACHR, 2001: para 86). It recognizes that the States, within their powers, regulate the acquisition and loss of this power, but the said sovereign power finds a limitation in "(...) the requirements of the integral protection of human rights" (IACHR, 2001: 88).

The ruling refers to previous advisory opinions ${ }^{14}$ (IACHR, 1984) in which the importance of nationality is recognized for the exercise of other rights, such as those derived from statelessness (IACHR, 2001: paragraph 91 et seq.). Likewise, it demonstrates the tension between the principle of sovereignty of the States and respect for human rights through the development of internal regulations ${ }^{15}$ (Carrillo, 2001: 32 ) to decide this type of issue.

In the case of the girls Yean and Bosico vs. The Dominican Republic ${ }^{16}$ (IACHR, 2005) ${ }^{17}$, the importance of nationality is reiterated and the Inter-American Court acknowledges the ignorance of this right in legal systems as an injury to the dignity of the person (IACHR 2005: para 179) every time the refusal by the Dominican State of the birth registration results in the cancellation of rights and places those affected in circumstances of extreme vulnerability (IACHR, 2005: para 180). For the IACHR, the right to nationality implies, on the one hand, the right to have a nationality so that the individual enjoys

2 If compared with the one that the ECHR produced.

13 IACHR, Ivcher Bronstein vs. Peru case, Series C, No. 74, of 6 February 2001.

14 See Advisory Opinion issued by the Inter-American Court of Human Rights, OC-4 of 1984 , Proposal to modify the Political Constitution of Costa Rica related to naturalization, Series A, No. 4, para. 32.

15 See Carrillo, J., Soberanía de los Estados y Derechos Humanos en Derecho Internacional Contemporáneo, second edition, Tecnos, Madrid, 2001, p. 32

16 IACHR, case of the girls Yean and Bosico vs. Dominican Republic, Series C, No. 130, of September 8, 2005..

17 The resolutions of provisional measures of 7 August 2000, 14 September 2000, 12 November 2000, 26 May 2001, 2 February 2006, 1 December 2011, 29 February 2012, and 7 September 2012 are of great importance in the subject. 
judicial protection for the relationship established with the State and on the other, the protection against arbitrary deprivation of the latter (IACHR, 2017: 11). In addition, that States are obliged to refrain from implementing practices that may favour the increase in statelessness cases (IACHR, 2017: 12).

For the Court, this right has a close relationship with the rights of children and the protection of the family, since the arbitrary denial of the birth registration and its delay constitutes a violation of the right to equality unknown of objective and reasonable criteria (Arlettaz, 2015: 431) and accentuates the condition of vulnerability of minors, as happened in the case of the girls Yean and Bosico vs. Dominican Republic ${ }^{18}$ (IACHR, 2005).

For the Inter-American Court, States must refrain from impeding access to registration and recognition of nationality by removing unnecessary requirements, especially when it comes to minors (IACHR, 2005: para 171). The omission caused the girls to be stateless, which resulted in victimization, as it established barriers to the exercise of a series of essential rights such as; personality development, access to education, development of own life project, access to the right to legal personality, right to name, dignified life, adequate standard of living, and family life.

The case of Dominican and Haitian people expelled vs. Dominican Republic ${ }^{19}$ (IACHR, 2014a) reiterates arguments of previous rulings on the treatment of Haitian or Haitianorigin persons in that country. By studying the right to nationality and family life, it addresses the best interests of the child from a differential approach ${ }^{20}$. The case determines that the condition of irregularity is a personal administrative situation that cannot be transferable or inheritable, meaning that the children of people who are undocumented cannot be affected by this situation and their right to nationality will have to be recognized (IACHR, 2014: para. 318). It is determined that the States may sovereignly establish the form of acquisition of nationality, however, they will have to reasonably set their restriction, so that a person who establishes links with the host State may not be considered as a transient in any case, since this must comply with a reasonable and temporary limit (IACHR, 2014: para 295).

From the considerations made, an evolutionary development of the scope of the right to nationality and legal personality is identified, as it turns out to be an essential element for the exercise of the right to name and for the effectiveness of nationality, which results in the recognition of guarantees that not only impact on civil and political rights, but also on economic, social and cultural ones.

\subsubsection{Procedural guarantees: a human right of all people}

The Vélez Loor v. Panama case ${ }^{21}$ (IACHR, 2010) deals with the protection of the rights to personal integrity and freedom and judicial guarantees based on human dignity 22 , noting that although the States have the exercise of their sovereignty, the power to

IACHR, case of the girls Yean and Bosico vs. Domenical Republic, Series C, No. 130, of 8 September 2005. 9 IACHR, Dominican and Haitian people expelled vs. Dominican Republic Series C, No. 282, 28 August 2014.

20 Paragraphs. $82-106,212-140$

21 IACHR, Velez Loor Vs. Panama case, Series C, No. 218, 23 November 2010.

22 This case concerns the arrest of Mr. Jesús Tranquilino Velez Loor, an Ecuadorian national detained in the border area of Darién (Panama) by police authorities in this country for not having documentation proving his stay in this country (par. 94). 
regulate the entry of nationals of other States has some limitations imposed by human rights.

Respect for such principles does not imply that the State cannot initiate any action to counteract irregular immigration, but that when adopting such measures, human rights must be respected. ${ }^{23}$ Foreigners detained in a social and legal environment different from their own with linguistic barriers exposes them to a condition of particular weakness ${ }^{24}$ (IACHR, 2010), an aspect that turns out to be incompatible in a democratic State.

The unworthy conditions of detention have been a concern for the Inter-American Court, because "(...) they may result in a violation of the absolute prohibition of cruel, inhuman or degrading treatment or punishment. ${ }^{25}$ In this sense, the States cannot invoke economic deprivations to justify conditions of detention that do not meet the minimum international standards in this area and do not respect the dignity of the human being" (IACHR, 2010: para 198). Likewise, these derive from a misconception that migratory administrative offenses involve crimes, which criminalizes migration ${ }^{26}$. It should be borne in mind that conditions worthy of detention should constitute good practice, applicable in detention centres exclusively for migrants and in prison establishments (IACHR, 2015: para 81 ) and comply with minimum circumstances such as legality, proportionality, reasonableness and prohibition of arbitrariness, as stated in the Nadege Dorzema $v$. Dominican Republic case. (IACHR, 2012: 133). From the foregoing, punitive migration policies that are intended to stop migrants in an irregular situation are incompatible with the ACHR (IACHR, 2014a: 359).

In immigration cases, the due process is a fundamental right of every migrant regardless of immigration status, which is recognized in the ACHR in Article 8. This is how every administrative and judicial body of a State party must respect it (IACHR, 2017: 44) and it is the duty of officials to be impartial and independent (IACHR, 2010: 108).

Another of the procedural guarantees in migratory causes consists of the obligation of the State that the person is presented before the competent authority and once this has happened, to watch over the fulfilment of the presumption of innocence in case an arrest has taken place (IACHR, 2014: 371), allow the measure or sanction to be reviewed, ensure that there are effective judicial remedies within the State (IACHR, 2010: 139), access justice and have legal assistance (IACHR, 2010: 254) or consular assistance if required, as happened in the case of Acosta Calderón v. Ecuador (IACHR, 2005a: 125) or establish communication with a person of his choice or consular agent, in case he has been legitimately detained as stated in the Tibi vs. Ecuador case (IACHR, 2004: 112).

23 These opinions had already been revealed in the Advisory Opinion, OC-18 of 2003, which will be analysed later in this paper.

24 See Ver IACHR Vélez Loor vs. Panama case, paras. 146-160

25 Committee against Torture, General Comment No. 2, Application of article 2 by States parties, 39 sessions, 2007, Doc. HRI/GEN/Rev.9 (Vol. II), of 27 May 2008. It is possible to point out that for the IACHR, the prohibition of torture, cruel, inhuman or degrading treatment or punishment is absolute, and in what relates specifically to immigrants, even those who are in a legal situation of irregularity, this rule has meant a strong limit to the individual expulsions or deportations of persons when in their home state their lives may be at risk or may be victims of torture, cruel, inhuman or degrading treatment or punishment.

26 The Report of the Special Rapporteur on the human rights of migrants, March 2011, paras. 13 and 15 , illustrates this. See Report of the Inter-American Commission on Human Rights, IACHR, Situation of human rights of unaccompanied families, children and adolescents, refugees, and migrants in the United States of America, 2015. 


\subsubsection{Equality and non-discrimination as the axis for all rights}

This normative prescription has great relevance, since it operates as an irradiating principle for the interpretation of rights, but it is also drawn as an instrumental guarantee for the application of other rights and even as an autonomous right. In the IACHR, it is found in almost all international instruments. Its application in migratory matters is vital, because although the right to equality is preached before the Law and discrimination is prohibited, as is the case with national origin, it is also permissible for States to make legitimate distinctions between nationals and foreigners, an aspect that is frequent in immigration policies.

The Inter-American Court has indicated that equality has entered the "domain of jus cogens" (IACHR, 2010: 248), which means that countries cannot tolerate behaviours that constitute discrimination. Several analyses of the rights of migrants arise, ranging from respect for the principle of equality and non-discrimination, such as the granting of nationality, judicial guarantees, to the application of the principle of non-refoulement. Despite this, in the case of Dominican and Haitian people expelled vs. Dominican Republic $^{27}$ (IACHR, 2014a), it says that States can have differentiated treatment between nationals and foreigners, as well as between documented and undocumented persons, provided they have objective motives that are reasonable and compatible with human rights (IACHR 2014a : para 403). This is frequent in the construction of migration policy and proposes the tension between sovereignty to establish limitations on the rights of foreigners and the emerging discussion about equality as a superior norm that is part of the ius cogens. To this end, the States have been invited to combat discriminatory practices at all levels and to adopt affirmative measures to guarantee equality of all persons submitted to their jurisdiction before the Law (IACHR, 2005: 155), which includes all migrants regardless of their legal status. This is because it seeks to ensure that there is no discriminatory treatment against certain categories of people and that progress is made towards a matching scheme between nationals and foreigners (Bosniak, 1991: 737).

\subsubsection{Expulsion of foreigners and the principle of non- refoulement: limitations on sovereignty}

The expulsion prohibition or return of foreigners is a guarantee constructed within the framework of the IACHR, both in the universal context ${ }^{28}$ and in the regional one ${ }^{29}$ and which has been influenced by the principle of "non refoulment" typical of International Refugee Law $^{30}$. It has developed from the application of the right to freedom of movement of foreigners within a State and is recognized in articles 22.8 and 22.9 of the ACHR.

Regarding the expulsion of foreigners ${ }^{31}$, the Inter-American Court emphasizes that the States are free to set entry and permanence requirements and that the expulsions

27 IACHR, Dominican and Haitian people expelled vs. Dominican Republic Series C, No. 282, 28 August 2014.

28 See, for example, article 13 of the Covenant on Civil and Political Rights and article 22 of the International Convention for the Protection of the Rights of all migrant workers and their families.

29 In the case of the European Human Rights Protection System, it is recognized in Article 4 of Protocol no. 4 and Protocol no. 7, Optional to the 1950 Rome Convention.

30 This guarantee originally arises in article 33 of the Geneva Convention on the Status of Refugees of 1951 .

31 Taking into consideration jurisprudence of provisional measures of Haitian and Dominican persons of Haitian origin, in OC-No. 18 of 2003, among others. apply 
authorized by the IACHR are those in which there is an individual analysis of each case, a due process and racial profiling is not produced ${ }^{32}$. The person's immigration history should be consulted, the nationality, the impact on the family breakdown due to the expulsion, the impact or disturbance in the life of the boy or the girl should be considered, and collective expulsions expedited without guarantees should be avoided ${ }^{33}$ (IACHR, 2014a). On the other hand, in migratory procedures, the purposes of the measures and the deprivation of liberty will have to be strictly distinguished and should only be used if necessary. Hence, immigration policies that involve compulsory detention are considered arbitrary, especially if they affect minors and involve expulsion (IACHR, 2014a: para 360).

The case of the Pacheco Tineo Family vs. the Plurinational State of Bolivia expands the scope of the prohibition by stating that the person may not be expelled or returned to their State of origin or to a third State, in case their right to life or liberty is in danger due to race, nationality, religion, social status, or political opinions (IACHR HR, 2013: 134), without any consideration for their immigration status, which shows a universal guarantee for every person. This pronouncement is based on what the ECHR has developed in this area (Salado, 2009:107), which limits the discretion of the States and which has been an underdeveloped aspect in the IACHR.

Individual expulsions may take place in cases when an individual proceeding is carried out with the characteristics already indicated, but it is a prohibition to perform them collectively, since in the opinion of the Inter-American Court, such decisions lack an objective analysis and are arbitrary (IACHR, 2012: 171).

\section{The Advisory Opinions: elements that integrate rights}

The advisory function of the Inter-American Court is classified as broad and unique in the IACHR, if a comparison is made with the universal and European systems (Salvioli, 2006: 5). Article 64 of the ACHR sets its scope with regard to legitimation, matters of interpretation and limitations (Nikken, 1999: 162). All American States members of the OAS, without having to be part of the ACHR, have the possibility of making consultations, as well as the specialized agencies of the OAS, which have competences in the area of human rights. With regard to the matters on which it can rule, it has determined that not only the norms emanating from the IACHR are within its competence, but also that it can have a say about any provision related to the protection of human rights of any treaty applicable to the American States, bilateral or multilateral in nature and that the OAS States may be party to them, including the reservations made and other instruments such as the DADH, and even on the compatibility of legislative projects of the States with the ACHR (Nikken, 1999: 166).

The value of the Advisory Opinions (AO) has been the subject of debate in the doctrine, since some maintain that they lack jurisdictional value (Faúndez, 1996: 450). However, there are those who affirm that the Inter-American Court is an autonomous judicial institution whose purpose is the application and interpretation of the ACHR, so its nature and decisions are jurisdictional in nature, which implies that it is an auxiliary

32 The provisions of Article 12 of the ICCPR and the provisions of OG No. 15 of the Human Rights Committee apply.

33 IACHR, Dominican and Haitian people expelled vs. Dominican Republic case, para. 379, and also IACHR, Vélez Loor Vs. Panama case, para. 146. 
jurisprudence of the IACHR and that it has been invoked in a large number of contentious cases (Nikken, 1999, 171), as happens in immigration.

To date, there have been three AO that refer to immigration or foreign persons' issues and they have been an evolutionary point for inter-American jurisprudence, since they establish a minimum standard of treatment regarding rights.

\subsection{Consular assistance as a nucleus for the exercise of rights}

AO-16 evidences the link between the right to information in the framework of consular assistance and the enjoyment of the rights inherent to the person according to the $\mathrm{ACHR}^{34}$ (IACHR, 1999). It analyses guarantees associated with due process and equal access to justice, and also says that states must eliminate as many barriers as possible to facilitate the right to effective defence through compensation measures in favour of vulnerable individuals, as with foreigners ${ }^{35}$. It should be kept in mind that such omission implies international responsibility from the State and creates the need to initiate a new process with due notice before the consular authority (Ortiz, 2013: 127). These considerations have been subject to pronouncement in contentious cases such as those already analysed, which show that it is necessary that migrants have effective consular attention from their States. Acosta Calderón vs. Ecuador (IACHR, 2005a: 125) and Tibi vs. Ecuador (IACHR, 2004: 112).

\subsection{The right to equality as an instrumental guarantee}

AO-18 of 2003 addresses three major issues; consideration of the principle of equality and non-discrimination as a "ius cogens" rule, recognition of some labour rights of undocumented persons and expulsion guarantees.

Regarding the first, the Inter-American Court concludes that the principle of equality and non-discrimination is a "jus cogens" rule on which all legal scaffolding of national and international public order rests (Hennebel, 2004: 747). It states: "Today, no legal act is admitted that conflicts with the said fundamental principle, discriminatory treatment is not allowed to the detriment of any person on grounds of gender, race, colour, language, religion or conviction, opinion political or other, national, ethnic or social origin, nationality, age, economic situation, property, marital status, birth or any other condition" (IACHR, 2003: 109).

Undocumented migrants must have decent treatment under the respect of certain minimum guarantees, because "the regular situation of a person in a State is not a necessary condition for that State to respect and guarantee the principle of equality and non-discrimination, since, as already mentioned, this principle is fundamental and all states must guarantee it to their citizens and to any foreign person in their territory" (IACHR, 2003: 113).

34 See IACHR, Right to Information on consular assistance within the framework of the guarantees of due legal process, para. 110 and following.

35 Ibid., para. 119. The Court indicated that: "(...) the real situation of foreigners who are subject to criminal proceedings, upon which their most valuable legal assets and, eventually, their very life (...) depend, must be taken into account. (...) The notification of the right to communicate with the consular representative of their country will contribute to considerably improve their defence possibilities (...)" (para. 120). 
What the Court said does not imply that a policy of open doors is given freeway (Chueca, 2005: 124), as countries may initiate actions against migrants who do not comply with the state legal system, it being legitimate to deal with documented and undocumented migrants differently. This provided that this differential treatment is reasonable, objective, proportional, and does not harm human rights (IACHR, 2003: paras 118 and 119).

Judgements on the importance of equality and the prohibition of discrimination have been a recurring theme, which, together with vulnerability, have characterized the decisions of contentious cases concerning migrants (IACHR, 2010: 248), (IACHR, 2014a), (IACHR, 2005: 155) and demonstrate the importance of evolving towards a path of equalization of rights in favour of the recognition of the dignity of the person, without the States completely losing their discretionary power to determine the contours of their immigration policy.

Regarding the rights derived from the labour relationship, the Inter-American Court again mentions human dignity and its importance for the rights of migrant workers. It states that the enjoyment of fundamental labour rights guarantees workers and their families a decent life. Workers have the right to perform a work activity in adequate and fair conditions and receive remuneration that allows them and their family members to enjoy an adequate standard of living compatible with dignity (IACHR, 2003: para 157).

This allows us to maintain that the Inter-American Human Rights System has made significant contributions in the difficult equality route between nationals and foreigners, and they have been worthy of being called "the certificate of quality in the field of human rights" (Chueca, 2005b: 61).

It should be noted that in this $\mathrm{AO}-18$, the Inter-American Court interprets provisions contained in the Universal Declaration of Human Rights, (UDHR) (UN, 1948) and ICCPR, requested in the consultation, and declares its competence in pointing out that they are international instruments on human rights and bind the consulting State (IACHR, 2003: para. 55). Although the consultation does not ask about aspects related to the International Convention on the protection of the rights of all migrant workers and their families (CRMW) (UN, 1990), the Court invokes this treaty because it considers it of vital importance for the development of the Convention (IACHR, 2003: paras. 69, 70, 75, 86, $128,131)$

\subsection{Good practices for the protection of migrant children}

AO No. 21 of 2014 addresses the rights of children and its main contribution is to recommend good practices to the States throughout the migration process. To this end, the Court refers to the importance of interpreting the American Declaration of Rights and Duties of Man, as well as its own jurisprudence ${ }^{36}$, the Convention on the Rights of the Child (CRC) (UN, 1989) and the OG of the $C^{37}$ (UN, 2005), considering them "opinio iuris comunis" regarding the protection of children's rights and contributing decisively to the interpretation of the ACHR (IACHR, 2014: 57). In addition, this AO also uses the

36 Dominican people of Haiti and Haitian origin vs. Dominican Republic case.

37 Committee on the Rights of the Child, OG-6/05, Treatment of unaccompanied children and separated from their family outside their country of origin, 39 period sessions, 2005, Doc. CRC/GC/2005/6, 1 September 2005. 
interpretation of the rules applicable to migrants in order to complete the necessary framework that provides protection to these persons with multiple vulnerability factors and to determine the scope of the obligations of the States.

It warns that the scope of protection derived from the ACHR and other treaties will be extended to every child, regardless of migration status, including refugees, migrants, asylum seekers and stateless persons (IACHR, 2014b: para 95).

Within the main defined obligations, States must adapt their regulations based on the application of the principle of useful effect (Sagüés, 2010: 118) for the enjoyment of rights in the context of migration. Hence the importance of procedures that States must take into account in the face of the risks that unaccompanied minors or separated from their families may suffer (victims of trafficking, sexual exploitation, participation in criminal activities or labour exploitation). To this end, it is necessary to have mechanisms for early detection of children in situations of migratory vulnerability (IACHR, 2014b: paras 90 and 93).

AO-21 points out the procedures to identify the international protection needs of migrant children such as the granting of asylum and shelter, no deprivation of the freedom of children regardless of their immigration status, creation of priority measures for the protection of minors, accommodation special conditions (IACHR, 2014b: para 106), respect for the principle of non-refoulement (IACHR, 2014b: para 207), and respect for family life (IACHR, 2014b: para 263). Under this approach, the United Nations Human Rights Council issued a report on the global problem of unaccompanied migrant children and adolescents and human rights, which highlights the good practices proposed by the IACHR in this area (United Nations General Assembly, 2017).

The foregoing allows us to maintain that the Inter-American Court does not seek to ignore the sovereignty of the States. Still, they must adapt their legislation to international treaties and develop a series of good practices in immigration matters, including: privilege the human rights approach, promptly identify minors at risk, respect due process, the right of children to personal liberty and return procedures may not at any time endanger the life or integrity of minors.

In this ruling, the Inter-American Court has resumed the considerations already made in contentious cases that have failed, in which the rights of children, the double vulnerability of minors and the protection of the family are the guiding axes of the decision, as happened in cases already analysed in contentious jurisprudence (IACHR, 2014a), (IACHR, 2005). According to the inter-American jurisprudence in this matter, the beginning of a new stage in the integral protection of the rights of children could be considered (Beloff, 2009: 17), since it sees minors in migratory status as a special protection objective within the IACHR.

\section{Conclusions}

The aforementioned jurisprudence shows that for the Inter-American Court, the issue of the rights of foreigners and immigrants has been of recent treatment, as in their decisions they have not been a cross-cutting issue addressed over the years. Despite this, it is possible to identify some contributions to the IACHR that have been produced thanks to the permanent dialogue between contentious decisions and the exercise of the advisory function. This is because in the latter, the Inter-American Court has been able to integrate 
in the framework of foreigners' rights interpretation parameters from the universal system that reinforce compliance with the obligations arising from the inter-American framework. This is the case of the application of the standards set by the CRC that have been inspiring to provide better protection for the rights of migrant children and people in need of international protection.

On the other hand, it is worth noting that the rulings of the jurisprudence regarding migrant workers have risen to a higher standard, the principle of equality and nondiscrimination, which is vital for countries to move towards recognition of the rights of these people under optimal parameters of dignity. Although there have not yet been contentious decisions regarding the rights of migrant workers, it is possible that the impact of AO-18 may favour the protection framework in this area.

The existing judgments, to a large extent, have addressed the protection of the rights regarding legal personality, name, nationality, prohibition of expulsion and requirements for it, as well as the application of the principle of equality and non-discrimination, labour rights, and derived benefits of the employment contract, regardless of the legal status of the immigrant. Likewise, it has studied issues such as guarantees in conditions of detention, children's rights and, more recently, it has recommended strict care protocols for unaccompanied minor migrants or those separated from their families. In this way, the rights of migrant workers and migrant children have set the guidelines for what can be considered an evolutionary development of jurisprudence in this area, giving rise to what may later be a corpus iuris in matters of migrants' rights.

The protection of these rights through the interpretation of the Inter-American Court constitutes a limitation to the sovereign power of the States, since in contentious cases it has imposed sanctions and reparation measures that must be accepted by the States; on the other hand, in the case of advisory opinions, they have set parameters for the interpretation of the norms that may well be assumed by the States in order to comply with the obligations derived from the treaties without implying a condemnation, that is to say, a construction of a favourable legal framework for migrants with a highly constructive sense.

Accordingly, it is necessary to have rulings with differential approaches in favour of migrant women and girls, as well as older adults, people with disabilities, LGBTI population and other differentiated groups, given that such issues have not yet been addressed. Also, taking into account that the legitimacy for the formulation of the consultations allows some bodies of the IACHR resort to interpretation, it would be appropriate that, for example, the Inter-American Commission of Women, the American Indian Institute and the Inter-American Children's Institute, could activate authority in order to achieve other rulings in these respect and achieve greater progress in the protection of rights.

Finally, in the decisions analysed by the Inter-American Court, elements of the advisory jurisprudence that have been used for the resolution of matters in contentious situations are found, as well as some axes for decision making in favour of the rights of migrants, including the concept of vulnerability, human dignity, equality and non-discrimination.

\section{References}

Asamblea General Naciones Unidas. (2017). "El problema mundial de los niños y 
adolescentes migrantes no acompañados y los derechos humanos". In Informe Final Del Comité Asesor Del Consejo de Derechos Humanos, 1-12. Retrieved from http://www.refworld.org/cgi-

bin/texis/vtx/rwmain/opendocpdf.pdf?reldoc=y\&docid=59cb96b94

Arlettaz, F. (2015). "La nacionalidad en el derecho internacional americano". In Anuario Mexicano de Derecho Internacional, (XV), 413-447. Retrieved from http://www.scielo.org.mx/pdf/amdi/v15/v15a11.pdf

Beloff, M. (2009). Los derechos del niño en el sistema interamericano, Buenos Aires:Editores del Puerto.

Bosniak, L. S. (1991). "Human rights, state sovereignty and the protection of undocumented migrants under the". In International Migration Review, 25(4), 737-770. Retrieved from http://www.jstor.org/stable/2546843\%5Cnhttp://www.jstor.org/page/info/about/polici es/terms.jsp

Carrillo, J. A. (2001). Soberanía de los Estados y Derechos Humanos en Derecho Internacional Contemporáneo. Madrid: Tecnos.

Chueca, A. (2005a). "La Convención sobre la protección de los Derechos de todos los Trabajadores Migratorios y de sus Familiares". In Revista de Derecho Migratorio Y Extranjería, (10), 117-126.

Chueca, A. (2005b). "Un análisis de las migraciones internacionales a través de cinco mitos". In Revista de Derecho Migratorio y Extranjería, (9), 45-63.

Consejo de Europa. (1963) Protocolo No.4 adicional al Convenio Europep de los Derechos Humanos y las Libertades Fundamentales, Estrasburgo, 16.IX, Retrieved from https://www.echr.coe.int/Documents/Convention_SPA.pdf

Consejo de Europa. (1984) Protocolo No.7 adicional al Convenio Europep de los Derechos Humanos y las Libertades Fundamentales, Estrasburgo,22XI, Retrieved from https://www.echr.coe.int/Documents/Convention_SPA.pdf

Corte IDH. (1984). Opinión Consultiva OC-4/84 del 19 de enero de 1984, Propuesta de modificación a la Constitución Política de Costa Rica relacionada con la naturalización. Retrieved from https://www.cejil.org/sites/default/files/i._opiniones_consultivas_de_la_corte_interame ricana_de_derechos_humanos.pdf

Corte IDH. (1999). Opinión consultiva OC-16/99 del 1 de octubre de 1999, El derecho a la información sobre la asistencia consular en el marco de las garantías del debido proceso legal. Retrieved from http://www.acnur.org/fileadmin/scripts/doc.php?file=fileadmin/Documentos/BDL/2001/ 0102

Corte IDH. (2001). Caso Ivcher Bronstein vs. Perú. sentencia de 6 de febrero de 2001. Retrieved from http://www.corteidh.or.cr/docs/casos/articulos/Seriec_74_esp.pdf

Corte IDH. (2003). Opinión Consultiva Oc-18/03 de 17, de Septiembre De 2003, Condición jurídica y derechos de los migrantes indocumentados, 127. Retrieved from http://www.acnur.org/t3/fileadmin/Documentos/BDL/2003/2351.pdf?view=1

Corte IDH. (2004). Caso Tibi vs. Ecuador. Sentencia de 7 de septiembre de 2004. 
Retrieved from http://www.corteidh.or.cr/docs/casos/articulos/seriec_114_esp.pdf Corte IDH. (2005). Caso de las niñas Yean y Bosico vs. República Dominicana. Sentencia, de 8 de septiembre de 2005. Retrieved from http://www.corteidh.or.cr/docs/casos/articulos/seriec_130_esp.pdf

Corte IDH. (2005 a). Caso Acosta Calderón vs. Ecuador. Sentencia de 25 de junio de 2005-129, Retrieved

from

http://www.corteidh.or.cr/docs/casos/articulos/seriec_129_esp1.pdf

Corte IDH. (2010). Caso Vélez Loor Vs. Panamá. Sentencia de 23 de noviembre de 2010, $1-100$. Retrieved

from http://www.acnur.org/t3/fileadmin/Documentos/BDL/2010/8140.pdf?view=1

Corte IDH (2012). Caso Ndege Dorzema y otros vs. República Dominicana. Sentencia de 24 de octubre de 2012-251. Retrieved from http://www.corteidh.or.cr/docs/casos/articulos/seriec_251_esp.pdf

Corte IDH (2013). Caso familia Pacheco Tineo vs. Estado plurinacional de Bolivia, Sentencia de 25 de novimebre de 2013, Retrieved from http://www.corteidh.or.cr/CF/jurisprudencia2/ficha_tecnica.cfm?nId_Ficha=376

Corte IDH. (2014a). Caso Personas dominicanas y haitianas expulsadas vs. República Dominicana. Sentencia de 28 de agosto de 2014. Retrieved from http://corteidh.or.cr/docs/casos/articulos/seriec_282_esp.pdf

Corte IDH. (2014b). Opinión consultiva oc-21/14 de 19 de agosto de 2014 Derechos y garantías de niñas y niños en el contexto de la migración y/o en necesidad de protección internacional. Retrieved from http://www.iin.oea.org/pdf-inn/Opinion-Consultiva-19agosto2014.pdf

Corte IDH. (2015). "Refugiados y migrantes en estados unidos familias y niños no acompañados". Organización de Los Estados Americanos. Retrieved from https://www.oas.org/es/cidh/informes/pdfs/Refugiados-Migrantes-EEUU.pdf

Corte IDH (2017). Cuadernillo de jurisprudencia de la Corte Interamericana de Derechos Humanos, personas en situación de migración y refugio. (2), Retrieved from http://www.corteidh.or.cr/publicaciones.html

Faúndez, H. (1996) El Sistema Interamericano de Protección de Derechos Humanos: aspectos institucionales y procesales. Instituto Interamericano de Derechos Humanos, Costa Rica.

Gozaíni, O. (2006). Incidencia de la jurisprudencia de la Corte Internamericana de Derechos Humanos en el Derecho Interno, Estudios constitucionales, (2), 335-362, Retrieved from http://www.pensamientopenal.com.ar/system/files/2018/08/doctrina46919.pdf

Gros, H. (1996). Análisis jurídico comparativo de las legislaciones sobre asilo en América Latina y los instrumentos internacionales y regionales (Estudios Básicos de Derechos Humanos, V), Instituto Interamericano de Derechos Humanos, 210-225, Retrieved from http://www.corteidh.or.cr/tablas/a12007.pdf

Hennebel, L. (2004). "I'humanisation du droit international des droits de I'homme: commentaire sur l'avis consultatif no. 18 de la cour interaméricaine relatif aux droits des travailleurs migrants (the humanization of international human rights law: observations 
under the inte)". In Revue Trimestrielle Des Droits Del L'homme, 59, 747. Retrieved from https://papers.ssrn.com/sol3/papers.cfm?abstract_id=1964939

Nikken, P. (1999). "La función consultiva de la Corte Interamericana de Derechos Humanos". In Biblioteca jurídica virtual del Instituto de Investigaciones Jurídicas de la UNAM, 161-180, Retrieved from https://archivos.juridicas.unam.mx/www/bjv/libros/5/2454/10.pdf

Nuñez, C. (2018). "La Jurisprudencia de la Corte Interamericana de Derechos Humanos frente a la movilidad humana: entre cosmopolistismo y hospitalidad". In Universitas,(27), 76-109, Retieved from https://e-revistas.uc3m.es/index.php/UNIV/article/view/4019

OEA (1948). "Carta de la Organización de Estados Americanos". In Novena Conferencia Internacional

Americana,

http://www.oas.org/es/sla/ddi/docs/tratados_multilaterales_interamericanos_A-

41_carta_OEA.pdf

OEA. (1948 A). "Declaración Americana de los Derechos y Deberes del Hombre". In Novena Conferencia Internacional Americana, 6. https://doi.org/10.1017/CB09781107415324.004

OEA. (1969). "Convención Americana sobre Derechos Humanos o Pacto de San José de Costa Rica". In Tratados Multilaterales Interamericanos, 24. Retrieved from http://www.oas.org/dil/esp/tratados_B-

32_Convencion_Americana_sobre_Derechos_Humanos.pdf

OEA. (2009). Reglamento de la Corte Interamericana de Derechos Humanos. Retrieved from http://www.corteidh.or.cr/sitios/reglamento/nov_2009_esp.pdf

ONU. (1948). Declaración Universal de Derechos Humanos, Retrieved from https://www.un.org/es/universal-declaration-human-rights/index.html

ONU. (1951). Convención sobre el Estatuto de los Refugiados, Retrieved from https://www.acnur.org/5b0766944.pdf

ONU. (1965). Convención internacional sobre la eliminación de todas las formas de discriminación racial, Retrieved from http://www.ohchr.org/SP/ProfessionalInterest/Pages/CERD.aspx

ONU. (1966). Pacto internacional de derechos civiles y políticos. Retrieved from http://www.ohchr.org/SP/ProfessionalInterest/Pages/CCPR.aspx

ONU. (1990). Convención internacional sobre la protección de los derechos de todos los trabajadores migratorios $y$ de sus familiares. Retieved from https://www.ohchr.org/sp/professionalinterest/pages/cmw.aspx

ONU. (1993). "Declaración y Programa de Acción de Viena". In Revista Internacional de La Cruz Roja, 18(118), 351. https://doi.org/10.1017/S0250569X00017015

ONU. (2005). "Convención sobre los derechos del niño trato de los menores no acompañados y separados de su familia fuera de su país de origen". In Comité de Los $\begin{array}{lllll}\text { Derechos Del Niño. } & \text { Retrieved }\end{array}$ http://poscla.org/libros/adultos/Convencion_derechos_nino.pdf

Olea, E.M. (2015). "Migración (en la jurisprudencia de la Corte Interamericana de Derechos Humanos)". In Economía. Revista en cultura de la legalidad.(9), 249-272. 
Retrieved

from

https://e-

revistas.uc3m.es/index.php/EUNOM/article/viewFile/2826/1522

Olmos. B. (2017). "Assesing the evolution of the Inter-American Court of Human Rights in the protection of migrants 'rights: past, present and future". In International Journal of Human Rights, Retrieved from http://dx.doi.org/10.1080/13642987.2017.1348736

Ortiz, L. (2013). Derechos humanos de los indocumentados. Valencia: Tirant Lo Blanch.

Ovalle, J.(2012). "La influencia de la jurisprudencia de la Corte Interamericana de Derechos Humanos en el derecho interno de los estados latinoamericanos". In Boletín mexicano de Derecho Comparado, (134)XLV, 595-623, Retrieved from http://www.scielo.org.mx/pdf/bmdc/v45n134/v45n134a5.pdf

Palacios, M. T. (2012). "La aplicación del principio de igualdad y no discriminación a los trabajadores migratorios". In Civilizar Ciencias Sociales Y Humanas, (12), 77-92. Retrieved from http://www.scielo.org.co/pdf/ccso/v12n22/v12n22a0.pdf

Quispe, F. (2016). "La protección de los derechos humanos en el sistema interamericano: su evolución y una visión actual". In Anuario Español de Derecho Internacional, (32), pp.225-258, DOI: 10.15581/010.32.225-258. Retrieved from https://earchivo.uc3m.es/bitstream/handle/10016/26589/proteccion_quispe_AEDI_2016.pdf?se quence $=3 \&$ isAllowed $=y$

Roa, J.E. (2015). La función consultiva de la Corte Interamericana de Derechos Humanos, Temas de Derecho Público, No. 94. Bogotá: Universidad Externado de Colombia.

Salado A.M. (2009). Los tratos prohibidos en el artículo 3 del Convenio Europeo de Derechos Humanos, (La Europa de los derechos: el Convenio Europeo de Derechos Humanos). Centro de Estudios Políticos y Constitucionales, Madrid.

Sagüés, N. (2010). "Obligaciones Internacionales y control de convencionalidad". In Estudios constitucionales, 8 (1), 117-136, https://dx.doi.org/10.4067/S071852002010000100005

Ventura, M.E y Zovato, D. (1989). La función consultiva de la Corte Interamericana de Derechos Humanos: naturaleza y principio. Instituto Interamericano de Derchos Humanos. Madrid: Civitas 